\title{
TELOMERE LENGTH, TELOMERASE ACTIVITY AND OXIDATIVE STRESS IN ELDERLY WITH CHRONIC CEREBROVASCULAR DISEASES ${ }^{*}$
}

\author{
M. Cherska ${ }^{1}$, D. Krasnienkov², V. Guryanov ${ }^{3}$,V. Kukharskyy ${ }^{2}$, \\ N. Tronko ${ }^{1}$, V. Kondratiuk ${ }^{3}$, O. Zabuga ${ }^{2}$ \\ ${ }^{1}$ SI «V. P. Komisarenko Institute of Endocrinology and Metabolism of the NAMS of Ukraine», Kyiv, Ukraine; \\ ${ }^{2} S I$ «D. F. Chebotarev Institute of Gerontology of the NAMS of Ukraine», Kyiv, Ukraine; \\ ${ }^{3}$ Bogomolets National Medical University, Kyiv, Ukraine \\ emariya83@gmail.com
}

Clarification of the mechanisms of biochemical changes in the development of cerebrovascular diseases is one of the major challenges to modern medicine. In recent years the increase in the ischemic forms of cerebrovascular diseases has been noted. Taking into account the progressive aging of the world's population, cerebrovascular diseases will remain relevant issue in the future. Chronic cerebral ischemia is a condition in which there is triggered a cascade of biochemical reactions in brain tissues, that leads to the intracellular accumulation of free radicals, activation of lipid peroxidation processes, excessive generation of reactive oxygen species and, as a result, neuron death. Like the other tissues, brain has its antioxidant system (superoxide dismutase, catalase, glutathione) which protects it from free radi- cals. Cerebral tissue is susceptible to oxidative stress due to its high oxygen demand. The glutathione (GSH) system is necessary to protect neurons under conditions of oxidative stress [1].

One of the main mechanisms of non-specific protection of organs and tissues from adverse factors is the activity of antioxidant systems that prevents free radical damage of living cells. It has been found that antioxidant defense mechanisms are universal in all living organisms [2]. With the development of modern concepts, the role of oxidative stress becomes more and more clear, that is the imbalance between prooxidants and antioxidant defense mechanisms of a body as the core source of pathogenesis of numerous acute and chronic conditions and diseases, such as atherosclerosis, diabetes mellitus, ischemia, etc. [3, 4].

* The research was carried out as part of investigation work at the SI «V. P. Komisarenko Institute of Endocrinology and Metabolism of the NAMS of Ukraine», Kiev. "To study features of cardiovascular system lesions and formation of coronary atherosclerosis in patients with diabetes mellitus» (State registration number: 0118U002163).

Institution, which financed the research: NAMS of Ukraine.

The authors assume responsibility for the published work.

The authors guarantee absence of competing interests and their own financial interest when carrying out the research and writing the article.

The manuscript was received by the editorial staff 24.01.2020. 
Prooxidant elements include all factors that play an active role in the increased formation of free radicals or other reactive oxygen species (ROS). In this case, both cellular (defects in mitochondrial respiration and specific enzymes) and exogenous mechanisms can participate. Ultimately, all these effects can lead to tension and subsequent decompensation of the mechanisms of antioxidant defense of a body and the development of oxidative stress that manifests itself at cellular, tissue and organ levels [3, 4].

One of the reasons for the different rate of aging of a heart and blood vessels is initially different genetic protection from external factors. Telomere length and telomerase activity can be considered as the important genetic markers of biological age of blood vessels. Telomeres are the terminal parts of a linear DNA molecule that are gradually shortened with every cell division. As soon as the length of telomeric DNA becomes dangerously short the induced cell aging launches while its metabolic activity remains maintained [5, 6]. There is the evidence that the length of telomeres in leukocytes reflects the length of telomeres in stem cells and corresponds to their length in endothelial progenitor cells that allows us to consider this parameter as the biomarker of vascular aging. Human telomerase is responsible for maintaining and lengthening telomeres and consists of the telomerase RNA component (TERC) and telomerase reverse transcriptase (TERT) which is its protein catalytic component. TERT uses TERC as the template for the addition of new telomeric DNA repeats to maintain telomere length. Some cells like stem cells, hematopoietic progenitor cells, activated lymphocytes, and most cancer cells have a high level of telomerase activity in order to elongate telomeres and support unlimited cell division. However, somatic cells generally have a low or "undetectable" level of telomerase activity. Telomere and its integrity are regulated by the interaction of telomerase and certain proteins [5]. Telomerase activity decreases with age but increases markedly in response to oxidative stress [5]. Therefore, telomeres are proposed to be the mitotic clock, which measures how many times a cell has divided. The number of telomeres that are lost during every cell division varies in different people. Previous studies have shown that increased oxidative stress and chronic inflammation are associated with higher telomere loss and accelerated telomere shortening. Several common risk factors of cardiovascular diseases such as smoking, diabetes, hypercholesterolemia, hypertension, obesity, low physical activity, alcohol consumption and psychosocial problems are associated with shorter telomeres. However, the mechanism underlying the relation of telomere shortening with these risk factors remains hypothetical. The aim of our study is to determine the relationship between telomere length and telomerase activity with indicators of oxidative stress in patients with cerebral atherosclerosis and type 2 diabetes.

\section{MATERIALS AND METHODS}

The comprehensive clinical and instrumental study involved 86 patients with CA. The diagnosis "Cerebral Atherosclerosis» has been formulated in accordance with the classification of atherosclerosis of World Health Organization since 2015 and confirmed by laboratory and instrumental research (Doppler ultrasonography of cerebral arteries, brain magnetic resonance imaging (MRI)).

Study design: simple, prospective, non-randomized, with sequential inclusion of patients.

The study did not include patients with all forms of atrial fibrillation, uncorrectable blood pressure $(\mathrm{BP})>160 / 90 \mathrm{~mm} \mathrm{Hg}$. Art., other rhythm disturbances requiring antiarrhyth- mic therapy, a decrease in EF $<40 \%$ assessed by two-dimensional echocardiography (Echocardiography), severe heart failure, renal and hepatic impairment, drug or alcohol dependence, and those who had been suffering from acute inflammatory diseases during previous month and other microvascular and macrovascular complications of DM. The patients who underwent revascularization as a result of unstable angina or myocardial infarction or rheumatic heart diseases did not participate in the study as well.

All patients underwent generally accepted clinical, laboratory (general blood and urine analysis, determination of lipid profile, creati- 
nine, urea, glucose, aspartate aminotransferase, alanine aminotransferase, bilirubin) and instrumental examination (transthoracic echocardiography, electrocardiography, ECG, transcranial Doppler ultrasound and brain MRI). All patients received antihypertensive drugs (perindopril and amlodipine) and metformin, if they had DM and didn't receive any statins.

The study protocol was approved by the ethics committees of the Institute of Endocrinology and Metabolism and the Institute of Gerontology NAMS of Ukraine). All participants had given the written informed consent. The Helsinki Declaration (2000) and applicable national standards regarding their participation in research were taken into account.

Blood samples were taken in the vacutainers containing EDTA. Within 30 minutes after blood sampling, peripheral blood mononuclear cells were isolated on the gradient $\left(1.077 \mathrm{~g} / \mathrm{cm}^{3}\right)$. After isolation, the cells were frozen and stored in liquid nitrogen at $-196^{\circ} \mathrm{C}$. DNA was isolated from thawed cells with the use of the phenolchloroform purification method [7]. The purity, concentration, and integrity of DNA were checked with the use of spectrophotometry and agarose gel electrophoresis.

Relative telomere length (RTL) was measured with the use of monochrome multiplex quantitative polymerase chain reaction (MMQPCR) [8]. Telomerase activity was determined by using a tandem repeat amplification protocol with real-time detection (TRAP) [9]. To determine the activity of blood catalase (EC 1.11.1.6), the blood hemolysate that was obtained by osmotic hemolysis of whole blood with distilled water and single freezing cycle followed by centrifugation was used. The diluted blood hemolysate was incubated with a hydrogen peroxide solution and the catalase activity was determined spectrophotometrically for the amount of the reaction product of the residual hydrogen peroxide with ammonium molybdate [10]. The activity of superoxide dismutase (SOD, EC 1.15.1.1) in the plasma of blood was determined by an indirect spectrophotometric method based on the reaction of superoxidedependent oxidation of quercetin, in an alkaline environment, in the presence of tetramethylethylenediamine [11]. The concentration of TBA-active products was measured using the reaction of heating malondialdehyde (MDA) with 2 -thiobarbituric acid (TBA) in an acidic medium to form the colored trimethine complex with the maximum of fluorescent radiation at $\mu=530 \mathrm{~nm}$ under conditions of the light excitation from $\mu=484 \mathrm{~nm}$. Plasma GSH in was determined by a spectrofluorometric method using orthophthalic aldehyde that results in the formation of highly fluorescent products from GSH, which are excited by the radiation at $350 \mathrm{~nm}$ and have the distinct fluorescence peak at $420 \mathrm{~nm}[1,12]$. The concentration of GSH has been calculated according to the calibration curve created using commercial GSH (Sinbias, Ukraine) and expressed in the micromoles per liter. The fluorescence intensity of the glycated proteins in blood plasma was measured by the excitation of $370 \mathrm{~nm}$ and emission of $440 \mathrm{~nm}$ using the Varioscan spectrofluorometer, and expressed in the arbitrary units of glycated protein micromoles per liter [13].

Systolic blood pressure (systolic blood pressure) and diastolic blood pressure (diastolic blood pressure) (mmHg) were measured twice using the standard sphygmomanometer in a sitting position after at least 10 minutes of rest. Plasma glucose levels were determined by the standard glucose oxidase method.

In order to provide the results in the case of quantitative variables, the average value of the indicator and its standard deviation $( \pm$ SD) for the case of the normal distribution law were calculated. Meantime the median value of the indicator $(\mathrm{Me})$ and the values of the first (QI) and third (QIII) quartile for the case of the distribution law, different from normal were calculated. The distribution was checked for normality using the Shapiro-Wilk test. To represent the qualitative features, their frequency (\%) had been calculated. When comparing the quantitative indicators in the two groups, the t-criterion (in the case of the normal distribution law), the Mann-Whitney criterion (in the case of the distribution law other than normal) were used. When comparing quality indicators, the Fisher's exact test was used. The threshold of significance for the all cases was set at $p<0.05$. The statistical analysis was performed with the use of the MedCalc v. 18.10 (MedCalc Software Inc., Broekstraat, Belgium, 1993-2018). 


\section{RESULTS AND THEIR DISCUSSION}

The patients were divided twice into the 2 groups depending on the relative telomere length and telomerase activity (please, refer to the tables 1 and 2). The median of the relative telomere length was 2.61. All patients with shorter telomeres than this indicator were referred to the group of short telomeres, and those who exceeded this value - to the group of long telomeres (table 1).

Similarly, the groups of patients with low and high telomerase activity were separated. The median telomerase activity was 3.16. All patients with the telomerase activity value lower than this indicator were referred to the low group, and those who exceeded this value - to the high group. The proportion of the men and women, as well as the number of patients with ischemic stroke and CA and type 2 diabetes was comparable in the both groups (table 2).

As a result of the comparative analysis, it has been found that in the patients with the CA and long telomeres, the statistically significantly higher level of catalase has been observed in contrast to the group with short telomeres.
Also in the group with high telomerase activity, the catalase and SOD levels are statistically significantly lower than in the group with low telomerase activity. It should be noted that the patients with long and short telomeres are comparable in age, and the age of the patients with low telomerase activity is statistically significantly greater.

Subsequently, during the correlation analysis, the statistically significant direct proportional relationship of telomere length with such oxidative stress markers as CAT and SOD $(r=0.23$ and $r=0.21$, respectively) and telomerase activity with GSH $(r=0.48)$ have been revealed. There is also detected the inverse proportion of the telomere length to type 2 diabetes $(r=-0.21)$. The telomere length and telomerase activity are not correlated with the other markers of oxidative stress.

\section{Discussion}

Telomeres are the terminal DNA-protein complexes that act as "protective caps» of linear chromosomes [14]. Telomeres shorten with

The main clinical characteristics and the markers of oxidative stress depending on the relative length of telomeres

\begin{tabular}{c|c|c|c}
\hline & $\begin{array}{c}\text { Long telomeres, } \\
(\mathbf{n}=\mathbf{5 6})\end{array}$ & $\begin{array}{c}\text { Short telomeres, } \\
(\mathbf{n}=\mathbf{3 0 )}\end{array}$ & $\mathbf{p}$ \\
\hline Catalase (CAT), U/ml & 599.68 & 532.65 & 0.023 \\
\hline Glutathione (GSH), $\mu \mathrm{M} / 1$ & $(526.66-637.99)$ & $3.58 \pm 0.19$ & 0.481 \\
\hline Superoxide dismutase (SOD), U/l & $3.52 \pm 0.2$ & 8.03 & 0.301 \\
\hline Thiobarbituroreactive Substances & 8.51 & $(7.87-8.51)$ & 0.664 \\
\hline (TBARs), $\mu \mathrm{M} / \mathrm{l}$ & $17.03-9.33)$ & 16.59 & 0.683 \\
\hline Glycation End Products (AGE), $\mu \mathrm{M} / 1$ & $(16.40-18.83)$ & $32.4 \pm 7.5$ & 0.079 \\
\hline Age & $31.1 \pm 7.6$ & $61.7 \pm 9.2$ & 0.99 \\
\hline Female & $65.8 \pm 10.9$ & $70 \%$ & 0.99 \\
\hline Male & $69.6 \%$ & $30 \%$ & 0.99 \\
\hline Smokers & $30.4 \%$ & $12 \%$ & 0.11 \\
\hline Patients with ischemic stroke & $10.8 \%$ & $33.3 \%$ & 0.81 \\
\hline Patients with diabetes mellitus & $51.8 \%$ & $33.3 \%$ & 0.99 \\
\hline
\end{tabular}

Note:

the average value $\pm \mathrm{SD}$ is given for the case of the normal distribution law, Me (QI; QIII) for the case of the distribution law other than normal. 
The main clinical characteristics and the markers of oxidative stress depending on telomerase activity

\begin{tabular}{c|c|c|c}
\hline & $\begin{array}{c}\text { High telomerase } \\
\text { activity, }(\mathbf{n}=\mathbf{5 6})\end{array}$ & $\begin{array}{c}\text { Low telomerase } \\
\text { activity, (n= 30) }\end{array}$ & $\mathbf{p}$ \\
\hline Catalase (CAT), U/ml & $\begin{array}{c}549.405 \\
(369.85-590.1)\end{array}$ & $\begin{array}{c}604.47 \\
(544.615-699.038)\end{array}$ & 0.026 \\
\hline Glutathione (GSH), $\mu \mathrm{M} / \mathrm{l}$ & $3.59 \pm 0.19$ & $3.46 \pm 0.18$ & 0.134 \\
\hline Superoxide dismutase (SOD), U/1 & 8.03 & 9.23 & 0.002 \\
\hline Thiobarbituroreactive Substances & $(7.75-8.37)$ & $(8.55-9.79)$ & 0.727 \\
\hline Glycation End Products (AGE), $\mu \mathrm{M} / 1$ & 16.97 & 17.81 & 0.772 \\
\hline Age & $32 \pm 6.8$ & $31.1 \pm 9.1$ & 0.021 \\
\hline Female & $61(57-70)$ & $66(61-79)$ & 0.63 \\
\hline Male & $67.9 \%$ & $73.3 \%$ & 0.63 \\
\hline Smokers & $32.1 \%$ & $26.7 \%$ & 0.99 \\
\hline Patients with ischemic stroke & $10.8 \%$ & $12 \%$ & 0.99 \\
\hline Patients with diabetes mellitus & $44.6 \%$ & $46.7 \%$ & 0.99 \\
\hline
\end{tabular}

Note:

the average value \pm SD is given for the case of the normal distribution law, Me (QI; QIII) for the case of the distribution law other than normal.

age, and telomere lengths are necessary, as suggested by some researchers, for the prediction of remaining life span [5]. It was shown, that telomeres length stronger associated with the pace of aging and age-related homeostatic dysregulation, than different panels of epigenetic clocks, including the 353-CpG clock, so telomeres length associated with some unique aspects of aging unrelated to other biomarkers [15].

Other authors believe that leukocyte telomere lengths are associated with oxidative stress and inflammation even in healthy people [16], which indicates that systemic oxidative stress and inflammation are associated with the increased risk of cardiovascular disease and may accelerate telomere shortening, thereby mitigating the effects of the hereditary component of TL [17]. In addition, considering the systemic effects of oxidative stress, inflammation, and the similar indicators of shortening of TL in somatic tissues [2], the rate of the shortening of TL in the blood cells reflects this in the vascular tissue. This theory implies that the shortening rate of TL can serve as the clinical biomarker of cardiovascular mortality.
However, it has been found that the change in the rate of shortening of leukocyte telomeres in adults is too low to significantly change TL in comparison to inheritance [16]. Since the variation is too small to modulate significantly the relationship between TL and clinical atherosclerosis, this result suggests that the higher rate of shortening of TL in the blood is more likely an epiphenomenon.

Recently, the lack of the relationship between the rate of shortening of leukocyte telomeres and atherosclerosis has also been demonstrated in the small longitudinal study [18]. At the same time, José Santiago Ibáñez-Cabellos et al. consider that oxidative stress is not the main cause of telomere shortening, and most likely oxidative stress is the potential cause of telomere shortening in those diseases, in which telomerase activity is impaired [6].

The identification of telomere shortening mechanisms is of particular interest at the present time because it can help to identify the physiological processes that underlie changes in health and life expectancy. The mechanisms of telomere shortening are well studied in cell culture, showing that oxidative stress is the key 
factor that accelerates telomere erosion [14]. However, cell cultures are not organisms, and in vitro oxidative stress levels are difficult to scale to the oxidative stress that is present the body. In this regard, the next question arises: Whether oxidative stress is also a factor of telomere shortening in vivo? We are aware of the six recent studies on the relationship between oxidative stress and telomere shortening in vivo that contain conflicting results, and their sample sizes were modest. Also these studies included few oxidative stress parameters that were measured after telomere shortening had already occurred, i.e. not in the period between the baseline and the subsequent growth of telomeres $[17,19,20]$. In this regard, it can be concluded that the role of oxidative stress in telomere shortening in vivo is currently unclear, and more extensive studies are required.

Thus, in our study we found that in the patients with the cerebral atherosclerosis, the association of some markers of oxidative stress with telomere length and telomerase activity was detected, regardless of the presence of con- comitant type 2 diabetes mellitus. In the patients with cerebral atherosclerosis with longer telomeres, the catalase level was statistically significantly higher than in the patients with short telomeres. The patients with the cerebral atherosclerosis with higher telomerase activity were characterized by statistically significantly lower levels of catalase and superoxide dismutase comparing to the patients with lower telomerase activity. The most stable direct correlation in this category of the patients was found between GSH and telomerase activity $(r=0.48)$, that may indicate the key role of GSH in the rate of telomere shortening and the development of atherosclerosis. It has been shown, that the telomerase could migrate to the mitochondria for the prevention of oxidative stress. Moreover, GSH also plays a key role in the regulation of the mitochondria mediated oxidative stress and related cell death. We are hypothesizing that such a strong correlation between GSH and telomerase could be observed because of their close connection to mitochondria mediated oxidative stress.

\section{REFERENCES}

1. Mokrasch LC, Teschke EJ. Anal Biochem 1984; 140: 506-509.

2. Nettle D, Andrews C, Reichert S, et al. Sci Rep 2017; 7: 40794 .

3. De Meyer T, Nawrot T, Bekaert S, et al. JACC 2018; 72: 805-813. doi: 10.1016/j.jacc.2018.06.014.

4. Magi F, Dimauro I, Margheritini F, et al. Free Radic Res 2018; 52: 639-647.

5. Bekaert S, De Meyer T, Rietzschel ER, et al. Aging Cell 2007; 6: 639-647. doi: 10.1111/j.1474-9726.2007.00321.x.

6. Ibanez-Cabellosa JS, Perez-Machadob G, Seco-Cerveraa M, et al. Redox Biology 2018; 14: 398-408. doi: 10.1016/j.redox.2017.10.004.

7. Sambrook J, Russell D. Cold Spring Harbor Protocols 2006; 1: 4455. doi: 10.1101/pdb.prot4455.

8. Cawthon R. Nucleic Acids Res 2009; 37: e21. doi: 10. 1093/nar/gkn1027.

9. Banerjee P, Jagadeesh S. Methods Mol Biol 2009; 1: 383-394. doi: 10.1007/978-1-59745-190-1_25.

10. Goth L. Clin Chim Acta 1991; 196: 143-151. doi: 10.1016/ 0009-8981(91)90067-m.
11. Kostyuk VA, Potapovich AI. Biochem Int 1989; 19: $1117-$ 1124.

12. Tukozkan Nurten, Husamettin Erdamar. Firat Tip Dergisi 2006; 11: 88-92.

13. Das BK, Sun TX, Akhtar NJ, et al. Invest Ophthalmol Vis Sci 1998; 39: 2058-2066.

14. Benetos A, Toupance S, Gautier S, et al. Circulation Res 2018;122: 616-623. doi: 10.1161/CIRCRESAHA.117.311751.

15. Belsky D, Moffitt T, Cohen A, et al. Am J Epidemiol 2018; 187(6): 1220-1230. doi: 10.1093/aje/kwx346.

16. Benetos A, Kark JD, Susser E, et al. Aging Cell 2013; 12: 615-621. doi: 10.1111/acel.12086.

17. Koriath M, Müller C, Pfeiffer N, et al. Biomolecules 2019; 9: 192. doi: 10.3390/biom9050192.

18. Toupance S, Labat C, Temmar M, et al. Hypertension 2017; 70: 420-425. doi: 10.1161/HYPERTENSIONAHA. 117.09354

19. De Meyer T, Rietzschel ER, De Buyzere ML, et al. Eur Heart J 2009; 30: 3074-3081.

20. Reichert S, Stier A, Zahn S, et al. Front Ecol Evol 2014; 2: 10114 . 


\title{
TELOMERE LENGTH, TELOMERASE ACTIVITY AND OXIDATIVE STRESS IN ELDERLY WITH CHRONIC CEREBROVASCULAR DISEASES
}

\author{
M. Cherska ${ }^{1}$, D. Krasnienkov ${ }^{2}$, V. Guryanov ${ }^{3}$,V. Kukharskyy ${ }^{2}$, \\ N. Tronko ${ }^{1}$, V. Kondratiuk ${ }^{3}$, O. Zabuga ${ }^{2}$ \\ ${ }^{1}$ SI "V. P. Komisarenko Institute of Endocrinology and Metabolism of the NAMS of Ukraine», \\ Kyiv, Ukraine; \\ ${ }^{2} S I$ «D. F. Chebotarev Institute of Gerontology of the NAMS of Ukraine», Kyiv, Ukraine; \\ ${ }^{3}$ Bogomolets National Medical University, Kyiv, Ukraine \\ emariya83@gmail.com
}

Background. Clarification of the mechanisms of biochemical changes in the development of cerebrovascular diseases is the one of the main problems of modern medicine.

The aim of our study is to determine the relationship of telomere length and telomerase activity with indicators of oxidative stress in patients with cerebral atherosclerosis (CA) and diabetes mellitus.

Methods. The clinical and instrumental study involved 86 patients with CA.

Results. The patients were divided twice into the 2 groups depending on the relative telomere length and telomerase activity. It has been found that the patients with CA with long telomeres have statistically significantly higher level of catalase (CAT) comparing to those from the group with short telomeres. Also, in the group with high telomerase activity the CAT and superoxide dismutase (SOD) levels are statistically significantly lower than in the group with low telomerase activity. It should be noted that the patients with long and short telomeres are comparable in age, and the age of the patients with low telomerase activity statistically significantly greater.

Conclusions. In the patients with CA the association of some markers of oxidative stress (CAT, SOD, glutathione (GSH)) with telomere length and telomerase activity has been detected, regardless of the presence of concomitant diabetes mellitus. The most stable direct correlation in this category of the patients has been found between GSH and telomerase activity $(r=0.48)$, that may indicate the key role of GSH in the rate of telomere shortening and the development of atherosclerosis.

Key words: cerebrovascular diseases, oxidative stress, telomerase activity, telomere length.

\section{ДЛИНА ТЕЛОМЕР, АКТИВНОСТЬ ТЕЛОМЕРАЗЫ И ОКСИДАТИВНЫЙ СТРЕСС У ПОЖИЛЫХ ПАЦИЕНТОВ С ЦЕРЕБРАЛЬНЫМ АТЕРОСКЛЕРОЗОМ И САХАРНЫМ ДИАБЕТОМ 2-ГО ТИПА}

\author{
Черская М. С. ${ }^{1}$, Красненков Д. С. ${ }^{2}$, Гурьянов В. Г. ${ }^{3}$, Кухарский В. М. ${ }^{2}$, \\ Тронько Н. Д. ${ }^{1}$ Кондратюк В. Е. ${ }^{3}$, Забуга O. ${ }^{2}$ \\ ${ }^{1}$ ГУ «Институт эндокринологии и облена веществ имени В. П. Колисаренко НАМН Украины», \\ г. Киев, Украина; \\ ${ }^{2}$ ГУ «Институт геронтологии имени Д. Ф. Чеботарева НАМН Украины», г. Киев, Украина; \\ ${ }^{3}$ Национальньй медицинский университет имени А. А. Боголольиа, г. Киев, Украина \\ emariya83@gmail.com
}

Выяснение механизмов биохимических изменений в развитии цереброваскулярных заболеваний является одной из основных проблем современной медицины.

Целью нашего исследования является определение взаимосвязи между длиной теломер и активностью теломеразы с показателями окислительного стресса у пациентов с церебральным атеросклерозом (ЦА) и сахарным диабетом 2 типа.

Методы. В клинико-инструментальном исследовании приняли участие 86 пациентов с ЦА.

Результаты. Пациенты были разделены дважды на 2 группы в зависимости от относительной длины теломер и активности теломеразы. Было обнаружено, что у пациентов с ЦА с длинными теломерами уровень каталазы статистически достоверно выше по сравнению с группой с короткими теломерами. Также в группе с высокой теломеразной активностью уровни каталазы (САТ) и супероксиддисмутазы (SOD) статистически достоверно ниже, чем в группе с низкой теломеразной активностью. Следует отметить, что пациенты с длинными и короткими теломерами сопоставимы по возрасту, а возраст пациентов с низкой активностью теломеразы был статистически значимо больше.

Выводы. У пациентов с ЦА выявлена связь некоторых маркеров окислительного стресса (CAT, $\mathrm{SOD}$, глутатиона (GSH)) с длиной теломер и активностью теломеразы, независимо от наличия сопутствующего сахарного диабета. Наиболее стабильная прямая корреляция в этой категории у пациентов была обнаружена между GSH и теломеразной активностью $(\mathrm{r}=0,48)$, что может указывать на ключевую роль GSH в скорости укорочения теломер и развитии атеросклероза.

К лючевые слов а: длина теломер, теломеразная активность, окислительный стресс, цереброваскулярные заболевания. 


\section{ДОВЖИНА ТЕЛОМЕР, АКТИВНІСТЬ ТЕЛОМЕРАЗИ \\ І ОКСИДАТИВНИЙ СТРЕС У ЛІТНІХ ПАЦІЄНТІВ \\ З ЦЕРЕБРАЛЬНИМ АТЕРОСКЛЕРОЗОМ І ЦУКРОВИМ ДІАБЕТОМ 2-ГО ТИПУ}

Черська М. С. ${ }^{1}$, Красненков Д. С. ${ }^{2}$, Гур'янов В. Г. ${ }^{3}$, Кухарський В. М. ${ }^{2}$, Тронько М. Д. ${ }^{1}$, Кондратюк В. С. ${ }^{3}$, Забуга O. ${ }^{2}$

${ }^{1}$ ДУ «Інститут ендокринологї̈ та обміну речовин імені В. П. Комісаренка НАМН України», м. Київ, Україна;

${ }^{2}$ ДУ «Інститут геронтології імені Д. Ф. Чеботарьова НАМН України», м. Київ, Украйна;

${ }^{3}$ Національний медичний університет імені О. О. Богомольия, м. Київ, Украӥна emariya83@gmail.com

З'ясування механізмів біохімічних змін в розвитку цереброваскулярних захворювань є однією з основних проблем сучасної медицини.

Метою нашого дослідження є визначення взаємозв'язку між довжиною теломер і активністю теломерази з показниками окисного стресу у пацієнтів з церебральним атеросклерозом (ЦА) і цукровим діабетом 2 типу.

Методи. У клініко-інструментальному дослідженні взяли участь 86 пацієнтів з ЦА.

Результати. Пацієнти були розділені двічі на 2 групи в залежності від відносної довжини теломер і активності теломерази. Було виявлено, що у паціентів з ЦА з довгими теломерами рівень каталази статистично достовірно вище в порівнянні з групою з короткими теломерами. Також в групі з високою теломеразной активністю рівні каталази (CAT) і супероксиддисмутази (SOD) статистично достовірно нижче, ніж в групі з низькою теломеразною активністю. Слід зазначити, що пацієнти 3 довгими і короткими теломерами порівнянні за віком, а вік пацієнтів з низькою активністю теломерази був статистично значимо більше.

Висновки. У паціентів з ЦА виявлений зв'язок деяких маркерів окисного стресу (CAT, SOD, глутатіону (GSH)) 3 довжиною теломер і активністю теломерази, незалежно від наявності супутнього цукрового діабету. Найбільш стабільна пряма кореляція в цій категорії у паціентів була виявлена між GSH і теломеразною активністю $(\mathrm{r}=0,48)$, що може вказувати на ключову роль GSH в швидкості укорочення теломер і розвитку атеросклерозу.

К л юч ові слов а: довжина теломер, теломеразна активність, оксидативний стрес, цереброваскулярні захворювання. 